\title{
The short-run effects of EU funds in Spain using a CGE model: the relevance of macro-closures
}

\author{
María Teresa Álvarez-Martínez ${ }^{1 *}$ and Clemente Polo²
}

\author{
*Correspondence: \\ maria.alvarez@ec.europa.eu \\ 1 JRC-Seville, European \\ Commission and Universidad \\ Loyola Andalucia, Seville, \\ Spain \\ Full list of author information \\ is available at the end of the \\ article
}

\begin{abstract}
This paper evaluates the impact of the structural and cohesion funds received by Spain in the period 2007-2013. The analysis is performed with a detailed computable general equilibrium (CGE) model calibrated with a SAM for Spain in 2005 elaborated by the authors, which contains highly detailed information on capital goods and tax rates. The aim of this paper is to quantify the short-run effects of the EU funds in the Spanish economy, which can help economic recovery. Additionally, it is evaluated to what extent these short-run effects may be over- or underestimated due to the closure rule used in this kind of models (neoclassical or Keynesian). The closure determines the endogenous variables in the market clearance conditions, and they affect the results of shocks in final demand. The conclusions show that neoclassical closure, used in previous CGE studies done for Spain, underestimates the impact they have on employment and GDP and captures a fictitious shock in private investment. In this case, employment and real GDP do not almost change, while under Keynesian rule they increase in 1.2 and $0.68 \%$, respectively. These results invalidate some of the estimates derived from previous studies and suggest that the best option to quantify the likely positive shortrun effects of raising public investment is only captured through Keynesian closure.
\end{abstract}

Keywords: Structural funds, Computable general equilibrium model, Investment goods, Closure rules

JEL Classification: C68, R53

\section{Background}

The impact of structural and cohesion funds is a matter of regional interest. The European Regional Development Fund (ERDF) and the European Social Fund (ESF) have spurred the economic growth of those European regions lagging behind the $75 \%$ of EU-15 (EU-25) average GDP per capita for more than 20 years. The construction of new infrastructures such as roads, bridges, sea ports, schools and hospitals has affected the economy of different regions, and eventually, they have changed national outlooks (De la Fuente 2003).

The main objective of this paper is to evaluate the short-run effects of the European Regional Funds received by Spain in 2007-2013, a period of economic crisis and 
recession, ${ }^{1}$ and analyze, with a highly detailed computable general equilibrium (CGE) model, to what extent these short-run effects may be overestimated or underestimated by the closure rule. In CGE models, closures determine what variables are endogenous and exogenous in market clearance conditions and the effects may be significantly different depending on the simulation (Rattso 1982; Lögfren et al. 2002). The most common closure is the neoclassical, where investment is an endogenous variable determined by public and private savings. This is the general rule used in previous studies elaborated for Spanish regions (Monrobel et al. 2013; Cardenete and Delgado 2012, 2013), where the effects of the funds are simulated altering final demand. In this case, the reaction of private investment is very sensitive to changes in foreign savings, which may over react, hiding the impact on employment (Álvarez-Martínez and Polo 2012). Keynesian closure can be a better option because private investment is an exogenous variable and there are no fictitious booms after altering other final demand components (Partridge and Rickman 1998). The results of this study are in line with this idea and the effects of regional funds on real GDP and employment found are bigger under Keynesian closure, which raise in 0.68 and $1.2 \%$, than under neoclassical, which does not almost change. As a consequence, these funds can play an important role in raising employment, a key macro variable in periods of economic recession. On the other hand, the database used in this paper is a social accounting matrix where private and public investments are disaggregated into six capital goods. This disaggregation allows more accurate simulations compared to previous national and regional studies where the allocation of the funds by priority axis and productive sectors was, in some cases, counterintuitive. The original theoretical approach used in this paper and a detailed literature review of CGE studies of cohesion funds in Spain can be found in Álvarez-Martínez (2014).

Several Spanish regions have been receiving European funds since 1986. In 2007, Spain was ranked as the second country by level of funds obtained, only surpassed by Poland (European Union 2008). As the time passes, the effects of the funds have been clearly reflected in the growth rate change in the regions classified under the threshold of $75 \%$ average GDP pc. Although variations in classifications are also due to statistical changes, ${ }^{2}$ the fact is that several Spanish regions have likely improved their relative position by the effects of the funds. Until 2006, 11 Spanish regions were considered objective 1, which are regions with a GDP pc below the $75 \%$ average of the EU-15. These regions were: Galicia, Principado de Asturias, Castilla y León, Castilla-La Mancha, Extremadura, Comunidad Valenciana, Andalusia, Region de Murcia, Ceuta, Melilla and Canarias. In 2007-2013, the classification changed. Three regions were removed from this category as a consequence of GDP improvements (Canarias, Castilla y León and Comunidad Valenciana), and four more were removed due to statistical changes (phasing-out regions): Asturias, Ceuta, Melilla and Murcia. In this case, the reference of the $75 \%$ of EU-15 average was replaced by the same figure for the EU-25. In the plan 20072013, the regions Objective 1 were: Andalucía, Galicia, Extremadura and Castilla-La

\footnotetext{
${ }^{1}$ The Spanish economy fell into recession in the last quarter of 2008 and the first quarter of 2012.

2 The pashing out regions are those regions that improve their position due to the statistical effect of incorporating new countries into the threshold. The phasing-in regions are those regions that actually improve their relative position.
} 
Mancha. Finally, in the most recent Cohesion policy plan for 2014-2020 only Extremadura remains in the group.

The impact of these policies is usually evaluated at regional level, since the affected regions are certainly the main beneficiaries. However, it is also relevant to quantify the demand effects for the whole country in the short run, especially in a period with high unemployment rates and low growth rates. As it is well known, the final objective of the EU funding a road is to improve transportation links and reduce costs. However, in the short run, there are other effects associated with the construction process as the raise of labor demand, related capital and intermediate material that may affect surrounding areas.

In 1995-2007, Spain went through an intense capital accumulation process and for more than a decade construction was the leading sector. The beginning of the economic recession in 2008 led the government to react raising public investment in order to boost final demand and reduce the growing unemployment rate. However, the fast increase in public deficit in 2010 forced the government to cut down investment and reduce to minimum current expenditure. Since then, the construction of public infrastructures funded by the EU has gained more relevance as a way to improve efficiency and employment and reduce costs.

The econometric approach has been used to evaluate the impact of structural funds on production and employment (Cancelo et al. 2009) and regional convergence (Leonardi 2005; Dall'erba and Le Gallo 2008; Ramajo et al. 2008). There are, however, few studies that use a CGE model to analyze demand/supply effects in EU countries (Gaspar and Pereira 1992; Lolos et al. 1995). In the case of Spain, several papers have been published recently about the demand effects (short run) of the structural funds in some Spanish regions using a multisectoral CGE model: Monrobel et al. (2013) for Madrid and Cardenete adnd Delgado $(2012,2013)$ for Andalucía. The paper at hand is in line with this part of the literature, since it also uses a CGE model to quantify the total impact of final demand shocks due to structural funds in Spain. It follows the theoretical approach detailed in Álvarez-Martínez (2014) and provides a sensitivity analysis on elasticities connected to the wage rate and production.

The structure of the paper is as follows. The database and the model are presented in Sects. 2 and 3, respectively. The simulations of raising public investment funded with structural/cohesion funds and co-finance by the Spanish Government under neoclassical and Keynesian closures are displayed in Sect. 4. The results are discussed in Sect. 5. Finally, Sect. 6 contains the main conclusions of the paper.

\section{Database: the social accounting matrix for Spain in 2005 (SAMES-05)}

A SAM is a balance matrix that closes the circular flow of income reflected in input-output matrices connecting income generation with expenditure. The SAMES-05 has been elaborated by the authors following the procedure of the SAMES-00 (Álvarez-Martínez and Polo 2014). The starting point is the input-output framework for Spain in 2005, the supply and use tables and the symmetric table at basic prices. The SAMES-05 is a 202by-202 square matrix at purchasers' prices with five agents: one household, the corporate sector, the Government, the rest of the EU and the rest of the world (ROW). There are 56 domestic production commodities/services that have been aggregated to 30 (Table 6), 
30 final supply goods/services and 30 consumption goods. Gross fixed capital formation is disaggregated into six public and six private capital goods (agricultural products, machinery and mechanical products, transport equipment, residential investment, other constructions and other products). Additionally, there is an account for stock variations; there are eight accounts for taxes (social security contributions of employees, employers and self-employees, taxes on production net of subsidies, VAT, taxes on imports and other taxes on products net of subsidies and direct taxes, which captures personal income tax and corporate tax); five accounts for transfers (property income, variation in pension fund reserves, unemployment benefits, welfare benefits and current transfers); two accounts for labor and capital; and one account for savings and stocks variation. Taxes on products net of subsidies have been disaggregated into net taxes on products, VAT and taxes on imports using the total figures from national accounts and sectoral data from the SAMES-00. The figures have been adjusted using a RAS algorithm. Similarly, the gross fixed capital formation in the matrix has been disaggregated by capital goods using the data on the GFCF matrices published by the INE. The distinction between public and private has been done with data from the SAMES-00. Like in this matrix, savings are revenues used to finance capital goods. The revenues are used to pay for VAT to the government and for final goods from total supply accounts used in the processing of capital goods. It is this investment disaggregation into capital goods what makes the SAMES-05 (and also the SAMES-00) more attractive to evaluate the effects of structural funds than previous databases, where there was not even distinction between public and private investment.

\section{The CGE model: the role of closure rules}

A CGE model is a consistent framework that combines microeconomic foundations with actual numbers for a given year to replicate the benchmark equilibrium. They capture the circular flow of income through a set of linear and nonlinear equations that accounts for prices and quantities.

\subsection{The core model}

In the model at hand, there are constant returns to scale and total supply is a CES combination of domestic production and imports from the EU and the ROW (Armington 1969). Total supply is a nested technology of linear and nonlinear production functions. At the second level, domestic supply is a Leontief function of intermediate inputs and value added and, at the lowest level of the nest, value added is a Cobb-Douglas aggregate of primary factors, labor and capital. Labor demand is subject to social security contributions of employers and employees. Domestic production is subject to taxes on production net of subsidies and total supply by product is subject to other taxes on products net of subsidies. Additionally, imports from the ROW are also taxed. ${ }^{3}$

Regarding consumption commodities, they are a Leontief combination of Armington products and they are taxed with VAT, such as households and government consumption pay value-added taxes. As usual, the representative household derives utility from

${ }^{3}$ The structure of the production function is shown in Figure 1 in "Appendix." 
a Cobb-Douglas combination of consumption and savings subject to their budget constraint, which accounts for labor income and current transfers from domestic and foreign agents in the economy. In the model, it is assumed that households dedicate a fixed proportion of savings to residential investment, which is also subject to VAT.

The government pays transfers to other agents in the economy. It pays subsides to industries and unemployment benefits to households. Government revenues come from taxes and transfers, and they finance consumption and investment. The difference between revenues and expenditures is denominated public surplus. In the model, tax revenues are endogenously determined and unemployment benefits depend on wages and the unemployment rate.

$$
\mathrm{PS}_{\mathrm{g}}=\mathrm{GI}_{\mathrm{g}}-\sum_{c=1}^{56} p_{\mathrm{c}} C_{\mathrm{g}}+\sum_{\mathrm{kg}=1}^{56} \sum_{i=1}^{56} p_{\mathrm{gi}} I g_{\mathrm{u}} b_{\mathrm{ikg}}-\mu \mathrm{wu} \bar{L}-p^{\mathrm{cpi}}\left(\mathrm{TRP}_{\mathrm{g}}+\mathrm{PIP}_{\mathrm{g}}+\mathrm{WFP}_{\mathrm{g}}\right)
$$

In Eq. 1, $\mathrm{PS}_{\mathrm{g}}$ is public surplus and $\mathrm{GI}_{\mathrm{g}}$ is government gross revenues. Public consumption commodities, $C_{\mathrm{g}}$, are valued at consumer prices, $p_{\mathrm{c}}$, and all transfers received are valued with the consumer price index, $p^{\mathrm{cpi}}$. $\mathrm{TRP}_{\mathrm{g}}, \mathrm{PIP}_{\mathrm{g}}$ and $\mathrm{BFP}_{\mathrm{g}}$ are current transfers, property incomes and welfare benefits paid by the government, respectively. $\mu$ is the proportion of the wages paid to unemployed in the base year, and $u$ is the unemployment rate. $\bar{L}$ is the exogenous labor supply, and $w$ is the nominal wage rate. Finally, $p_{\text {gi }}$ is the price of public investment goods, $\operatorname{Ig}_{\mathrm{u}}$, disaggregated by products using the coefficients $b_{\mathrm{ikg}}$, which capture the demand of each product needed to product a unit of public capital good. Government consumption and investment are exogenous variables in the model, and their corresponding prices in Eq. 1 include the VAT rates paid. In this case, public investment is also subject to value-added taxes.

Finally, the foreign sectors (EU and ROW) obtain revenues from imports, residents' consumption, labor endowments, taxes and transfers. These revenues are used to pay for exports, non-residents consumption and taxes and transfers. The difference between revenues and expenditures is the foreign current balance (FS) with the EU and the ROW. The foreign current balance of the EU can be defined as:

$$
\begin{aligned}
\mathrm{FS}_{\mathrm{eu}}= & \sum_{j=1}^{56} p_{\mathrm{eu}} Y_{\mathrm{euj}}+w \bar{L}^{\mathrm{reu}}(1-u)+\mathrm{PSSCEC}_{\mathrm{eu}} \cdot \operatorname{SSCEC}+\mathrm{PSSCHC}_{\mathrm{eu}} \cdot \mathrm{SSCHC} \\
& +\operatorname{PDTAX}_{\mathrm{eu}}\left(\mathrm{GI}_{\mathrm{h}} \cdot \tau^{\mathrm{itph}}+\mathrm{GI}_{\mathrm{cs}} \cdot \tau^{\mathrm{cs}}+p_{\mathrm{c}} \mathrm{DTAX}_{\mathrm{eu}}\right)+\mathrm{PTIM}_{\mathrm{eu}} \cdot \mathrm{TIMR}+\mathrm{PVAT}_{\mathrm{eu}} \cdot \mathrm{VATR} \\
& +\mathrm{PTPR}_{\mathrm{eu}} \cdot \mathrm{TPRR}+\mathrm{PTP}_{\mathrm{eu}} \cdot \mathrm{TPR}+p^{\mathrm{cpi}}\left(\mathrm{PIR}_{\mathrm{eu}}+\mathrm{WBR}_{\mathrm{eu}}+\mathrm{TRR}_{\mathrm{eu}}+\mathrm{RC}_{\mathrm{eu}}\right)-\sum_{i=1}^{56} p_{\mathrm{eu}} X_{\mathrm{eui}} \\
& -p^{\mathrm{cpi}}\left(\mathrm{PIP}_{\mathrm{eu}}+\mathrm{DTAXP}_{\mathrm{eu}}+\mathrm{SSCEP}_{\mathrm{eu}}+\mathrm{SSCHP}_{\mathrm{eu}}+\mathrm{WBP}_{\mathrm{eu}}+\mathrm{TRP}_{\mathrm{eu}}+\mathrm{NRC}_{\mathrm{eu}}\right)-w \bar{L}_{\mathrm{h}}^{\mathrm{f}}-\Theta
\end{aligned}
$$

where $p_{\text {eu }}$ is the price of imports from the $\mathrm{EU}\left(Y_{\text {euj }}\right)$ and $\bar{L}^{\text {reu }}$ is the EU non-residents labor supply. PSSCEC and PSSCHC are the share coefficients of EU in total revenues from social security contributions of employers (SSCEC) and employees (SSCHC). Similarly, PDTAX $\mathrm{eu}_{\mathrm{eu}}$ is the share coefficient on total direct taxes revenues and

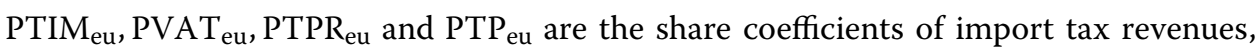
VAT, other net taxes on products and other net taxes on production. Transfers from the 
EU as cohesion and structural funds are included in this equation in variable $\Theta$, which is expenditure for the $\mathrm{EU}$. Finally, $\mathrm{RC}_{\mathrm{eu}}$ is residents' consumption in the $\mathrm{EU}$ and $\mathrm{NRC}_{\mathrm{eu}}$ non-residents consumption from the EU. Savings from the ROW, $\mathrm{FS}_{\mathrm{ew}}$, have been calculated in the same way but without including in the equation tax revenues/subsidies transfers and the shock variables for the cohesion and structural funds. Tax revenues from VAT are transferred to EU in a fixed percentage, and the total amount depends on total domestic VAT revenues. Similarly, other tax revenues are transferred to the EU using fixed proportions derived from the data in the benchmark.

\subsection{Closure rules}

As mentioned, closure rules determine what variables are endogenous or exogenous, which clearly affects the results in CGE models. Variables like public consumption and investment, public deficit, exports, exchange rates and foreign current balances can be fixed or variable depending on the closure. According to the literature, there are several options regarding primary factors, government accounts, the foreign sector and private investment. Productive factors, like capital and labor, can be plenty used or under tapped; this is the case of unemployment and/or capital stock under used in periods of economic recession. On the other hand, public deficit/surplus can be the adjusting variable when tax rates and public consumption are exogenously determined; or just the other way around, to assume that public savings and public consumption are fixed and tax rates are endogenous. Usually, this case is known as Johansen closure rule. It could be also the case that public savings and taxes rates are fixed and public consumption may change. The behavior of the foreign sectors is very important. In this case, if the current balance is fixed, the exchange rate is endogenous, or in an opposite way, if the current balance is fixed, the exchange rate adjusts. Alternatively, exports can be considered as endogenous or exogenous. Finally, and what is more important for the analysis at hand, there are two options for defining the relationship between private investment and savings in the model. If private investment is endogenous (neoclassical), it adjusts to match private and public savings (savings-driven model); however, if it is fixed (Keynesian), then private savings are calculated as a ratio on households' incomes (investmentdriven) and they adjust to match the value of investment.

The closures used in this paper are neoclassical and Keynesian. In both scenarios, the assumptions for the three first features: factors market, government and foreign deficit, are the same. Capital services are plenty used while labor is underused and there is unemployment. Public consumption and investment are exogenously determined and it is public deficit the adjusting variable. The foreign current accounts, external savings, are endogenous, and the exchange rate with the ROW is fixed and equal to one in all simulations. The main difference in the two cases is basically due to private investment, which is endogenous in the neoclassical scenario and fixed under Keynesian rule. The wage equation is ruled out in the latter version.

Neoclassical closure assumes that private investment is endogenously determined by changes in domestic and foreign savings. In this case, the equilibrium condition is:

$$
p_{\mathrm{s}} \sum_{j=1}^{56} \mathrm{NRI}_{j}=p_{\mathrm{s}}\left(S_{\mathrm{h}}-S_{\mathrm{hr}} S_{\mathrm{h}}\right)+S_{\mathrm{cs}}+\mathrm{PS}_{\mathrm{g}}+\mathrm{FS}_{\mathrm{eu}}+\mathrm{FS}_{\text {row }}-\sum_{j=1}^{56} p_{j} \mathrm{VS}_{j}
$$


where $\mathrm{NRI}_{j}$ is the non-residential private investment, $S_{\mathrm{hr}}$ is the ratio of private residential investment over households' savings in benchmark and $\sum_{j=1}^{56} p_{j} \mathrm{VS}_{j}$ is the value of inventory changes.

In this setting, a negative external shock from the domestic viewpoint such as a fall in foreign savings sets up an implausible negative investment increase in the economy in order to match the value of total savings. Under Keynesian closure rule, aggregate investment is exogenously determined and it is the sum of private savings, the government deficit and the current account deficit that adjusts to equal the value of investment when there is a negative external shock. In this case, an investment boom is ruled out by hypothesis and the real wage-unemployment equation present in neoclassical closure is removed from the model.

\section{Simulations and scenarios}

In this paper, the same simulation is performed under two different scenarios, neoclassi$\mathrm{cal}$ and Keynesian. The increase in public investment funded with resources from the EU and co-funded by national public administrations is calculated using information from the European Commission (2012), operational program "cohesion fund-ERDF." The structural funds provided by the EU for the period 2007-2013 were 1356 million euros and the amount co-funded by national administrations was 339 million euros. The structural European funds (ERDF) have been allocated to two priority axis, environment, nature, water resources and risk prevention (12\%) and transport and energy (88\%), while the cohesion funds have been allocated to environment and sustainable development, trans-European transport network and technical assistance. The funds disaggregated by year are available in the operational program. We have disaggregated the national funds by year using the percentage of structural funds allocated to each year over the total funds for the period 2007-2013. The amount of resources corresponded to each year is given in Table 1.

It is important to deflate all figures in current euros to euros in 2005, which is the base year of the SAMES-05. The deflator is estimated using nominal and real gross fixed capital formation from INE, the Spanish National Statistics Office. Real GFCF index has been calculated with data on volume index. Hence, the deflators in Table 2 are applied to numbers in Table 1 . The resulting figures appear in Table 3.

Table 1 National and European funds (in euros). Source Spain: operational program "cohesion fund-ERDF"

\begin{tabular}{lccr}
\hline Objective & ERDF & National & \multicolumn{1}{c}{ Cohesion } \\
\hline 2007 & $174,793,142$ & $43,698,286$ & $1,270,265,976$ \\
2008 & $188,577,350$ & $47,144,338$ & $917,767,168$ \\
2009 & $192,669,128$ & $48,167,282$ & $550,660,301$ \\
2010 & $197,248,059$ & $49,312,015$ & $280,836,753$ \\
2011 & $201,918,566$ & $50,479,642$ & $229,162,791$ \\
2012 & $206,682,483$ & $51,670,621$ & $175,309,535$ \\
2013 & $195,062,606$ & $48,765,652$ & $119,210,484$ \\
$2007-2013$ & $1,356,951,334$ & $339,237,834$ & $3,543,213,008$ \\
\hline
\end{tabular}


Table 2 Gross fixed capital formation (GFCF). Source INE (Spanish National Statistics Office)

\begin{tabular}{llllll}
\hline & GFCF nominal & $\begin{array}{l}\text { GFCF volume } \\
\text { index }\end{array}$ & $\begin{array}{l}\text { Nominal index } \\
\text { (growth) }\end{array}$ & $\begin{array}{l}\text { Real index } \\
\text { (growth) }\end{array}$ & Deflator index \\
\hline 2005 & 267,444 & 93.789 & - & - & - \\
2006 & 301,263 & 100.464 & 1.126 & 1.071 & 1.052 \\
2007 & 323,216 & 104.949 & 1.209 & 1.119 & 1.080 \\
2008 & 312,046 & 100.000 & 1.167 & 1.066 & 1.094 \\
2009 & 247,396 & 82.013 & 0.925 & 0.874 & 1.058 \\
2010 & 232,481 & 77.515 & 0.869 & 0.826 & 1.052 \\
2011 & 216,695 & 73.332 & 0.810 & 0.782 & 1.036 \\
2012 & 197,541 & 68.185 & 0.739 & 0.727 & 1.016 \\
\hline
\end{tabular}

Table 3 Total funds (in million euros). Source Spain: operational program "cohesion fundERDF" \& INE

\begin{tabular}{lccc}
\hline & ERDF & National & Cohesion \\
\hline 2007 & 139.52 & 34.88 & 1176.15 \\
2008 & 148.56 & 37.14 & 838.68 \\
2009 & 157.01 & 39.25 & 520.54 \\
2010 & 158.93 & 39.73 & 267.02 \\
2011 & 165.13 & 41.28 & 221.14 \\
2012 & 172.40 & 43.10 & 172.55 \\
2013 & 191.99 & 48.00 & 117.33 \\
$2007-2013$ & 1133.54 & 283.39 & 3313.42 \\
\hline
\end{tabular}

The simulation under the two scenarios is directly affecting three equations in the model: public deficit (1), the EU balance of payments (2) and the closure rule equation (3). Public deficit is directly affected because of the increase in public investment in 283 million euros that are funded by the national government. This expenditure will reduce public savings and consequently public deficit will rise. Total national funds in the period 2007-2013 are used to increase public investment in "other constructions."

On the other hand, the flow of income coming from the EU, 1133.54 and 3313.42 million euros, is going to modify foreign savings. Usually, these transfers are accounted as capital transfers from the EU, which reduces the foreign current balance. In national accounts, the balance of the current account is equal to the balance in the capital account but with opposite sign in order to keep a zero balance in the balance of payments. Taking into account that capital transfers are not explicitly included in the SAMES-05, the structural and cohesion funds in the model have been included as an exogenous reduction in the debt with the EU trough a shock in variable $\Theta$, (Eq. 2). The main purpose is to include these transfers without increasing the debt that the country has with the EU. Finally, the raise of public investment in "other constructions" funded with national and European funds is simulated increasing the parameter $\operatorname{Ig}_{\mathrm{u}}$ in Eq. 1 in 4730 million euros. This simulation captures better the impact of the funds than other previous studies for the Spanish regions where the effects on EU savings are totally missed and there is a misallocation of funds among industries. The amount of resources devoted to energy 
Table 4 Public revenues and expenditures (in percentage variation)

\begin{tabular}{|c|c|c|c|}
\hline & Base year & S1: NEO & S2: KEY \\
\hline Total revenues & $420,816.00$ & 1.253 & 0.881 \\
\hline Property income & 7349.00 & 0.022 & -0.634 \\
\hline Total income tax & $99,105.00$ & 0.029 & -0.348 \\
\hline Income tax (households) & $63,555.61$ & 0.038 & -0.393 \\
\hline Income tax (corporate) & $35,549.39$ & 0.013 & -0.269 \\
\hline SSCE & $87,271.00$ & 0.096 & -0.200 \\
\hline $\mathrm{SSCH}$ & $17,313.00$ & 0.093 & -0.215 \\
\hline SSCS & 9306.00 & 0.080 & -0.215 \\
\hline Current transfers & $83,326.00$ & 0.022 & -0.634 \\
\hline Taxes on production net & 5088.00 & 0.036 & 0.220 \\
\hline Taxes on imports & 130.00 & -0.335 & -0.379 \\
\hline VAT & $55,598.00$ & 1.361 & 0.909 \\
\hline Taxes on products net & $40,996.00$ & -0.217 & -0.253 \\
\hline Capital & $15,334.00$ & 0.000 & 0.000 \\
\hline Total current expenditures & $373,878.00$ & 0.024 & -0.997 \\
\hline Public consumption & $171,787.00$ & 0.036 & -1.013 \\
\hline Property income & $17,506.00$ & 0.022 & -0.634 \\
\hline Unemployment benefits & 5811.80 & -0.263 & -12.812 \\
\hline Other social benefits & $96,124.20$ & 0.022 & -0.634 \\
\hline Current transfers & $82,649.00$ & 0.022 & -0.634 \\
\hline Public investment & $32,552.80$ & 14.904 & 14.137 \\
\hline Non-residential public investment & $30,890.60$ & 17.794 & 16.893 \\
\hline Agriculture products & 29.50 & 0.018 & -0.515 \\
\hline Machinery and mechanical products & 3622.00 & 0.026 & -0.735 \\
\hline Transport equipment & 598.80 & 0.026 & -0.728 \\
\hline Other constructions & $24,244.70$ & 22.665 & 21.712 \\
\hline Other products & 2395.60 & 0.021 & -0.608 \\
\hline Residential public investment & 1662.20 & 0.027 & -0.751 \\
\hline Public surplus & $-14,385.20$ & -2.185 & 15.503 \\
\hline
\end{tabular}

and environmental infrastructures cannot be simulated raising final demand on industries related to these sectors. Instead, the funds finance infrastructures that improve efficiency and energy saving. In the short run, these effects can only be evaluated affecting the Construction sector.

The model is calibrated using the SAMES-05. Production elasticities are taken from GTAP $^{4}$ and the unemployment rate in 2005 is $9.16 \%$ (INE). The price of capital is fixed as numeraire.

\section{Results}

The results of simulations on the main macroeconomic variables are presented in Tables 4, 5 and 6, and their effects are discussed in Sect. 5.1. The sectoral results are presented in Sect. 5.2, and finally, a sensitivity analysis is displayed in Sect. 5.3.

\footnotetext{
${ }^{4}$ GTAP (Global Trade Analysis Project) is a database that describes bilateral trade, transport, production, intermediate commodities, etc. for a big set of regions-countries. The GTAP database is frequently used in many CGE models. It is periodically updated. Further information can be found at: https://www.gtap.agecon.purdue.edu/default.asp.
} 
Table 5 Macroeconomic variables

\begin{tabular}{lrrr}
\hline & Base year & S1: NEO & S2: KEY \\
\hline Main aggregates and welfare index (\% variation) unemployment rate is in percentage & & & \\
Unemployment rate (\%) & 9.16 & 9.132 & 8.097 \\
Employment growth rate & - & 0.031 & 1.170 \\
Variation of households' net disposable income & $612,277.00$ & 0.040 & -0.365 \\
Variation of consumer price index & & 0.022 & -0.634 \\
Households' welfare & $36,929.34$ & 0.017 & 0.278 \\
Nominal GDP & $908,792.00$ & 0.115 & -0.049 \\
Real GDP & $908,792.00$ & 0.090 & 0.681 \\
Demand side aggregate variables (\% variation) & & & \\
Private consumption & $545,763.00$ & 0.040 & -0.365 \\
Total private investment & $234,489.20$ & -2.414 & -0.589 \\
Non-residential private investment & $155,335.40$ & -3.664 & -0.703 \\
Residential private investment & $79,153.80$ & 0.040 & -0.365 \\
Public consumption & $171,787.00$ & 0.036 & -1.013 \\
Public investment & $32,552.80$ & 14.904 & 14.137 \\
EU current balance & $20,965.00$ & -24.529 & -18.932 \\
ROW current balance & $46,807.00$ & -0.475 & 0.314 \\
\hline
\end{tabular}

\subsection{Macroeconomic variables}

The most significant effect of the cohesion and structural funds in simulation S1 on public accounts, see Table 4, is the increase in total public investment in almost $15 \%$ due to the raise of "other constructions" in $22.7 \%$. The increase in final demand of public investment raises construction production and also labor and capital demand, but unemployment benefits only fall in $0.26 \%$. All other public expenditures remain almost equal to their corresponding values in the benchmark, and the effect on total current expenditures is negligible. However, public revenues increased in $1.25 \%$, a figure that almost matches the raise of VAT revenues, $1.36 \%$. In the current model, public investment is subject to VAT and the positive variation of public investment affects tax revenues. The impact of this policy in VAT revenues and also in VAT transfers to the EU is missing in previous studies for Spain, and even in the studies implemented for other countries. In this case, the increase in public investment funded by the European Union, and cofunded by the national government, leads to a significant raise in VAT revenues, which reduces public deficit in $2.2 \%$.

In simulation S2, the effects on public revenues are bigger than in simulation S1. Under Keynesian closure, private investment is exogenously fixed and changes in cohesion and structural funds will affect domestic and foreign savings. In this case, the raise of public investment in "other constructions" of $21.7 \%$ increases total public investment in $14.1 \%$. The small differences on these figures compared to those in simulation S1 are due to changes in prices since in both cases they are exogenous variables in real terms. The impact on current expenditures is, however, quite different. They fall in $1 \%$, basically due to the significant reduction in unemployment benefits, around $13 \%$. The increase in production raises tax revenues on production, $0.22 \%$, and the raise of public investment increases VAT revenues, $0.9 \%$, which also raises public revenues in $0.9 \%$. In this 
Table 6 Variation of prices and production

\begin{tabular}{|c|c|c|c|c|}
\hline \multirow[t]{2}{*}{ Sector } & \multicolumn{2}{|c|}{ Domestic production } & \multicolumn{2}{|c|}{ Domestic prices } \\
\hline & S1: NEO & S2: KEY & S1: NEO & S2: KEY \\
\hline Agriculture and fishing & -0.021 & 0.124 & 0.017 & -0.487 \\
\hline Mining & 0.094 & 0.404 & 0.022 & -0.631 \\
\hline Production and distribution of electricity, gas and water & -0.036 & 0.421 & 0.018 & -0.514 \\
\hline Food and tobacco & 0.010 & 0.229 & 0.023 & -0.663 \\
\hline Textile, wearing apparel and leather & -0.015 & 0.370 & 0.026 & -0.744 \\
\hline Wood and wood products & 0.345 & 1.203 & 0.026 & -0.738 \\
\hline Pulp, paper and paper products & -0.134 & 0.328 & 0.025 & -0.712 \\
\hline Publishing and printing & -0.286 & 0.361 & 0.026 & -0.731 \\
\hline Chemicals and rubber & -0.019 & 0.356 & 0.025 & -0.710 \\
\hline Other non-metallic mineral products & 1.086 & 2.101 & 0.025 & -0.695 \\
\hline Basic metals and metal products & -0.167 & 0.907 & 0.026 & -0.737 \\
\hline Machinery and equipment n.e.c. & -0.984 & 0.545 & 0.027 & -0.763 \\
\hline Electric and electronic machinery & -0.832 & 0.574 & 0.026 & -0.746 \\
\hline Motor vehicles and other transport equipment & -0.838 & 0.197 & 0.026 & -0.745 \\
\hline Other manufactures & -0.457 & 0.560 & 0.027 & -0.765 \\
\hline Construction & 1.558 & 2.854 & 0.027 & -0.751 \\
\hline Trade & -0.162 & 0.456 & 0.024 & -0.676 \\
\hline Hotels and restaurants & 0.011 & 0.256 & 0.021 & -0.608 \\
\hline Transport & -0.002 & 0.418 & 0.022 & -0.625 \\
\hline Financial intermediation & -0.029 & 0.434 & 0.025 & -0.694 \\
\hline Real estate activities & -0.400 & 0.212 & 0.011 & -0.302 \\
\hline Other business activities & -0.734 & 0.376 & 0.028 & -0.783 \\
\hline Market education & -0.013 & 0.331 & 0.029 & -0.824 \\
\hline Market health and social work & -0.013 & 0.297 & 0.028 & -0.781 \\
\hline Other market activities & -0.199 & 0.272 & 0.023 & -0.653 \\
\hline Public administration & 0.000 & 0.000 & 0.036 & -1.006 \\
\hline Non-market education & 0.000 & 0.036 & 0.043 & -1.228 \\
\hline Non-market health and social work & 0.000 & 0.007 & 0.039 & -1.099 \\
\hline Other non-market activities & 0.000 & 0.018 & 0.030 & -0.841 \\
\hline Private households with employed persons & -0.009 & 1.018 & 0.049 & -1.369 \\
\hline
\end{tabular}

simulation, public savings adjust, and in order to match the closing rule, public deficit raises almost $16 \%$.

The main macroeconomic variables are presented in Table 5. In simulation S1, it can be observed there are no significant variations in the unemployment rate that changes from 9.16 to $9.13 \%$, as could be expected after checking the short fall of the unemployment benefits. Employment and real GDP growth rates are almost zero and the low change in household net disposable income keeps the initial figures for private consumption, without improving utility. However, the effects on the unemployment are more significant in simulation S2. The unemployment rate falls from 9.16 to $8 \%$ due to the funds, and employment increases in $1.2 \%$. The lower production prices lead CPI to fall in $0.64 \%$. This variation in wages and prices reduces household net disposable income, $-0.37 \%$, and nominal GDP, $-0.05 \%$, while household welfare and real GDP rise in 0.28 and $0.68 \%$. In this case, the effects on private investment are only due to price changes since investment is exogenous and there is not any negative impact. The number of jobs 
created according to these results is around 361,000. In 2013, there were 2,061,000 less jobs than in 2005 (INE 2014), but according to the figures obtained in simulation S2, this number would had been almost $18 \%$ higher without cohesion and structural funds. The main policy implication derived from this result is that cohesion and structural funds also played an important role in raising output and creating new jobs.

On the other hand, in neoclassical closure S1, the only significant effects are on private investment, which fall in $2.4 \%$, and on the directly affected variables: the EU current balance and the public investment, which fall in $25 \%$ and increase in $15 \%$, respectively. In S1, the increase in public investment is basically funded by the European Union. However, since private investment is determined by the variation of domestic (households, corporations and public deficit) and external savings (from the EU and the ROW), the changes in public deficit and EU current account affect private investment and fall 3.7\%. Residential private investment does not change because it has been included in the model as a fixed percentage of household savings. These results suggest that neoclassical rule does not provide realistic results when the simulated policy raises final demand. In this case, the effects of savings are counteracted by the same range of variation in private investment keeping constant all other variables. These unrealistic results hide the likely positive impact of raising public investment on employment and GDP. This outcome reinforce the initial idea of the relevance that funding public infrastructures may have in the short run.

\subsection{Sectoral results}

If we look at sectoral results in S1 in Table 6, domestic production increases in construction $(1.55 \%)$, other non-metallic products $(1.09 \%)$ and wood and wood products (0.34\%). Nonetheless, domestic production declines in almost all other industries such as machinery and equipment, electric and electronic machinery and motor vehicles and other transport equipment. The effects on these sectors are due to the cut down of nonresidential private investment motivated by the change in foreign savings. The effects on prices are negligible for all products. This is a savings-driven model, such as private investment adjusts to variations in total savings. The increase in final demand due to public investment is counteracted by the reduction in private investment, and the general equilibrium effects are rather small.

In simulation S2, sectoral production and prices capture higher effects compared to the previous scenario. Domestic production increases in all industries, especially in construction (2.8\%), the directly affected sector, other non-metallic mineral products $(2.1 \%)$ and wood and wood products (1.2\%). Regarding prices, there is a general reduction. The reason is that the increase in labor demand reduces wages and the fall in production cost is transferred to domestic production prices. Under Keynesian closure, there is no a real wage equation, like in the neoclassical scenario.

Results are very sensitive to closures. Keynesian closure seems to be more realistic to evaluate the impact of the funds than neoclassical, where only private investment and the balance of payments seem to be affected. Simulation S1 does not account for the positive effects on employment, and households do not seem to take advantage of short-run impact of a bigger final demand. These results suggest that future regional (or national) studies focus on the final demand effects generated by the funds should pay 
special attention to the performance of simulations. Not only the closure rule is important, but also the implementation of final demand shocks in the appropriate sectors (see Álvarez-Martínez 2014).

\subsection{Sensitivity analysis}

The two previous simulations have been evaluated multiplying the wage curve elasticity and the Armington elasticities from GTAP by 1.25 and 0.75 . The results for the main macroeconomic variables are displayed in Tables 7 and 8 in "Appendix." Under neoclassical closure, first we evaluate a change in the wage curve elasticity and second the variation on Armington elasticities (columns S1 and S2, respectively, in Tables 7 and 8). The variation of Armington elasticities is also studied for Keynesian closure. We do not include a sensitivity analysis of a joint variation in wage and Armington elasticities for neoclassical closure because the results are exactly the same of those in the sensitivity analysis for the wage elasticity. In general, the results show no big differences on macro variables. Under neoclassical closure, the adjusting mechanism is the same and changes in private investment prevent the model to adjust production to the increase in public investment. Hence, there are no changes in total final demand and domestic or total supply does not adjust to the new situation independently of the production elasticity. Regarding the range variation of results in Keynesian scenario, it can be observed that the central results are in line with results of the sensitivity analysis. They do not differ much. The higher the elasticity of production, the higher the effects on the employment growth rate and households' net disposable income. In conclusion, it can be said that the results derived from the sensitivity analysis reinforce the results obtained in the central case.

\section{Conclusions}

This article evaluates the short-run effects of the structural and cohesion funds cofinanced by the Spanish government in a period of economic crisis, 2007-2013. In general, most cohesion policy analyses have been performed at regional level, especially if we take into account what their main purposes are: improve productivity and competitiveness, reduce transport cost and reach socioeconomic convergence in all European regions. However, many researchers have evaluated the short-run demand effects these funds may in targeted regional economies, and we believe that part of these effects has also affected surrounding areas.

A highly detailed CGE model has been elaborated and calibrated with a social accounting matrix for Spain in 2005 under two closure rules: neoclassical and Keynesian. The advantages of this model compared to previous models are three. First, the detailed SAMES-05 displays public and private investment disaggregated by capital goods, which allows more precise simulations increasing the capital goods to what the funds are aimed. In this case, we increase public investment in "other constructions" to evaluate the impact of higher investments in roads, ports, energy infrastructures, etc. It is avoided the misallocation of funds among industries. Second, public investment is taxed with VAT. Consequently, the results also capture the impact that an increase in final demand has on VAT revenues, public deficit and even tax transfers to the EU. And 
finally, the shock in the foreign current balance also captures the impact these funds have in the balance of payments, also omitted in other publications.

The analysis is performed with two different closures in order to check how technical issues can underestimate or oversize the impact of the structural funds. The results suggest that the impact of the funds on macroeconomic variables under neoclassical closure is almost negligible. The positive effect on employment and real GDP observed under Keynesian closure is hidden under neoclassical. Thus, the main conclusion is that on evaluating the short-run effects of EU structural funds, the only way is to assume that private investment is endogenously determined. The Keynesian rule provides more realistic results, and the sensitivity analysis on the production elasticities corroborates this idea.

The main policy recommendation that can be extracted from this study is that EU cohesion funds must be observed also as an important short-run policy to spur economic growth. The main objective of these funds has always been to improve competitiveness and reach convergence among regions in the medium/long run. This study proves that the effects on employment and GDP in the short run can be significant for the whole country of Spain and can help to counteract the increase in unemployment. According to the results under Keynesian rule, the funds have avoided the destruction of almost 18\% more jobs over the total jobs destroyed in the period 2007-2013.

Authors' contributions

MTAM elaborated the database. CP and MTAM elaborated the model, the discussion on the results, the conclusions and the writing. All authors read and approved the final manuscript.

Author details

${ }^{1}$ JRC-Seville, European Commission and Universidad Loyola Andalucia, Seville, Spain. ${ }^{2}$ Unidad de Fundamentos del Análisis Económico, Universidad Autónoma de Barcelona, Catalonia, Spain.

Acknowledgements

We are very grateful for the useful comments from the editor and two anonymous referees.

Competing interests

The authors declare that they have no competing interests.

Availability of data and material

Additional information on data and other material is available upon request.

Disclaimer

The views expressed are purely those of the authors and may not in any circumstances be regarded as stating an official position of the European Commission.

Ethics approval and consent to participate

The authors declare that this study does not involve human subjects, human material and human data.

\section{Appendix}

See Fig. 1 and Tables 7 and 8. 


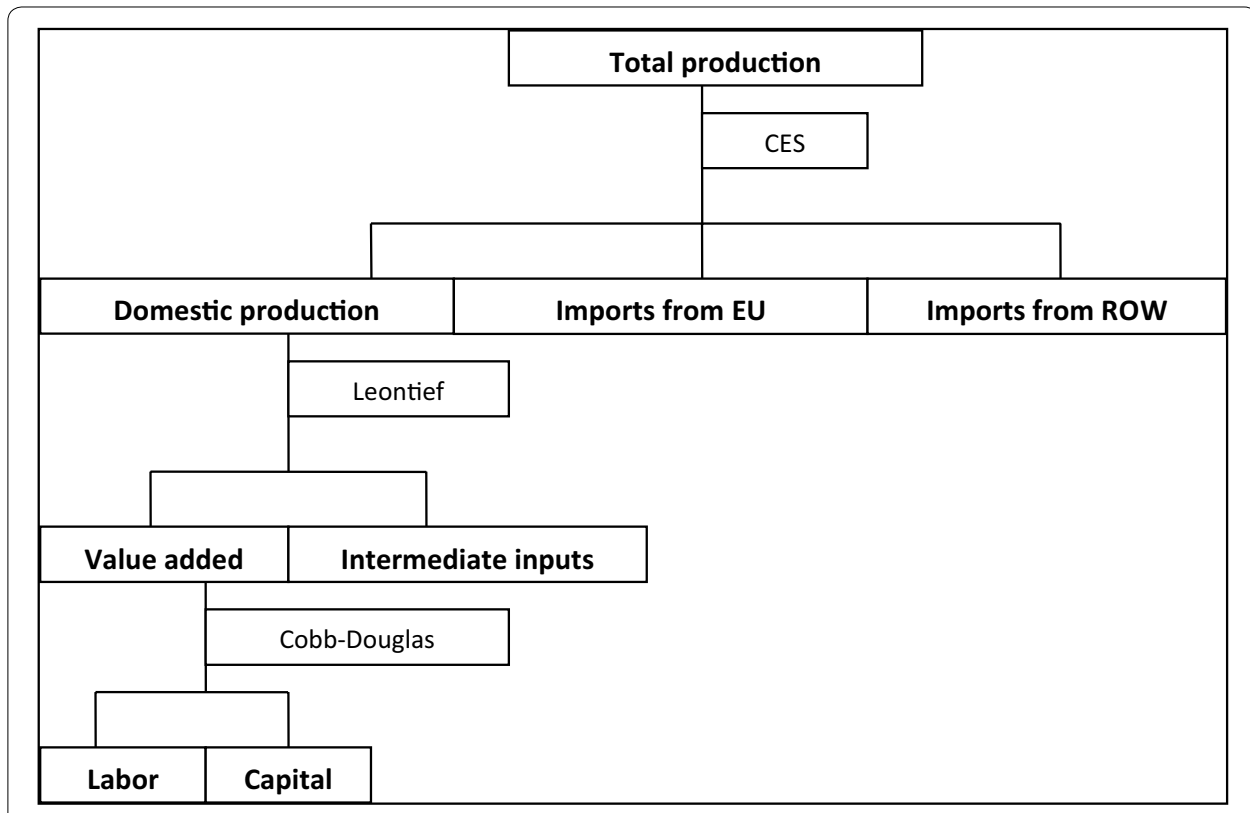

Fig. 1 Nested production function

Table 7 Elasticities on the wage rate (S1) and elasticities of production multiplied (S2 and S3) by 1.25

\section{Base year S1: NEO-wage S2: NEO-prod S3: KEY-Prod}

Main aggregates and welfare index

Unemployment rate (\%)

$9.16 \quad 9.128$

9.132

8.094

Employment growth rate

Variation of households' net disposable income

$612,277.00$

0.035

0.031

1.174

Variation of consumer price index

Households' welfare

Nominal GDP

$28,220.33$

0.038

$-0.365$

Real GDP

$908,792.00$

0.020

0.040

$-0.634$

0.022

0.279

Demand side aggregate variables

$908,792.00$

$-0.049$

0.115

0.683

Private consumption

$545,763.00 \quad 0.038$

0.090

$-0.365$

Total private investment

$234,489.20-2.408$

0.040

$-0.590$

Non-residential private investment

Residential private investment

$155,335.40$

$-3.654$

$-2.414$

$-0.704$

$79,153.80 \quad 0.038$

$-3.664$

$-0.365$

Public consumption

$171,787.00 \quad 0.032$

0.040

$-1.014$

Public investment

$32,552.80 \quad 14.902$

0.036

14.136

EU current balance

$20,965.00-24.510$

14.904

$-19.009$

ROW current balance

$46,807.00 \quad-0.472$

$-0.476$

0.328 
Table 8 Elasticities on the wage rate (S1) and elasticities of production multiplied (S2 and S3) by 0.75

\section{Base year S1: NEO-wage S2: NEO-prod S3: KEY-prod}

Main aggregates and welfare index

Unemployment rate (\%)
Employment growth rate
Variation of households' net disposable
Variation of consumer price index
Households' welfare
Nominal GDP
Real GDP
Demand side aggregate variables
Private consumption
Total private investment
Non-residential private investment
Residential private investment
Public consumption
Public investment
EU current balance
ROW current balance

9.16

$28,220.33$

$908,792.00$

$908,792.00$

$545,763.00 \quad 0.041$

$234,489.20-2.422$

$155,335.40$

$79,153.80$

$171,787.00$

$32,552.80$

$20,965.00-24.553$

$46,807.00 \quad-0.479$

\subsection{6}

0.026

0.041

0.016

0.116

0.087

$-3.677$

0.041

0.040

14.907

ROW current balance

\section{Publisher's Note}

Springer Nature remains neutral with regard to jurisdictional claims in published maps and institutional affiliations.

Received: 6 March 2017 Accepted: 10 August 2017

Published online: 06 September 2017

\section{References}

Álvarez-Martínez MT (2014) The effects of the European structural funds in the Spanish regions using CGE models: a review. Investig Reg 29:129-138

Álvarez-Martínez MT, Polo C (2012) A general equilibrium assessment of external and domestic shocks in Spain. Econ Model 29:2486-2493

Álvarez-Martínez MT, Polo C (2014) A new social accounting matrix for Spain with investment disaggregated by capital goods. Estad Esp 183:5-37

Armington P (1969) A theory of demand for products distinguished by place of production. IMF Staff papers 16: 157-178

Cancelo JR, Faíña JA, López-Rodríguez J (2009) Measuring the permanent impact of European structural funds on peripheral objective 1 regions: the case of galicia. Eur Plan Stud 17:1535-1558

Cardenete MA, Delgado MC (2012) Impact assessment of the European Structural Funds in Andalusia: 2000-2006. Empirical Econ Lett 11:1157-1162

Cardenete MA, Delgado MC (2013) Analysis of the impact of the European funds in Andalusia in 2007-2013 using a general equilibrium model. Mod Econ 4:448-452

Dall'erba S, Le Gallo J (2008) Regional convergence and the impact of European structural fund 1989-1999: a spatial econometric analysis. Pap Reg Sci 82:219-244

De la Fuente A (2003) El impacto de los Fondos Estructurales: convergencia Real y Cohesión Interna. Hacienda Públ Esp 165(2):129-148

European Commission (2012) Programa Operativo de Fondo de Cohesion-FEDER 2007-2013, Brussels (Belgium)

European Union: Regional Policy (2008) Cohesion policy 2007-13: national strategic reference frameworks. Office for Official Publications of the European Communities, Luxembourg

Gaspar V, Pereira AM (1992) A dynamic general equilibrium analysis of EC structural funds, working paper 191, Facultade de Economía, Universidade Nova de Lisboa

INE (2014) Encuesta de Poblacion Activa, Madrid

Leonardi R (2005) Cohesion policy in the European union: the BUILDING of Europe, Basingstoke, Palgrave

Lögfren H, Lee Harris R, Robinson S, Thomas M, El-Said M (2002) A standard computable general equilibrium (CGE) model in GAMS. Microcomputers in policy research, vol 5. International Food Policy Research Institute, Washington

Lolos S, Suwa-Eisenmann A, Zonzilos N, Bourgignon F (1995) Evaluating the CSF with an extended computable general equilibrium model: the case of Greece (1988-1995). J Policy Model 17:177-197 
Monrobel JR, Cámara A, Marcos MA (2013) Modelling European regional policy 2007-2013: applied general equilibrium analysis of the economic impact on the Madrid region. Eur Plan Stud 21(2):264-280

Partridge MD, Rickman DS (1998) Regional computable general equilibrium modeling: a survey and critical appraisal. Int Reg Sci Rev 21:205-248

Ramajo J, Márquez M, Hewings G, Salinas M (2008) Spatial heterogeneity and interregional spillovers in the European union: Do cohesion policies encourage convergence across regions? Eur Econ Rev 52:551-567

Rattso J (1982) Different macroclosures of the original Johansen model and their impact on policy evaluation. J Policy Model 4:85-97 